\title{
TOTAL AND HETEROTROPHIG RESPIRATION IN A TROPICAL LOWLAND FOREST, PAHANG, PENINSULAR MALAYSIA
}

\author{
Jeyanny $\mathbf{V}^{1, *}$, Wan-Rasidah $\mathbf{K}^{1}$, Muhammad-Firdaus $\mathbf{S}^{2}$, Tran-Van $\mathbf{D}^{3} \&$ Muhammad-Asri $\mathbf{L}^{1}$ \\ ${ }^{1}$ Forest Research Institute Malaysia, 52109 Kepong, Selangor Darul Ehsan, Malaysia \\ ${ }^{2}$ Faculty of Agriculture, Universiti Putra Malaysia, 43400 Serdang, Selangor Darul Ehsan, Malaysia \\ ${ }^{3}$ Silviculture Research Institute, Vietnamese Academy of Forest Sciences, Hanoi, Vietnam \\ *jeyanny@frim.gov.my
}

Submitted January 2020, accepted July 2020

\begin{abstract}
Soil respiration is the second largest flux in the carbon (C) cycle, contributing close to $40 \%$ of annual atmospheric input. It was hypothesised that partitioning total soil respiration (Rs) and heterotrophic respiration $(\mathrm{Rh})$ during wet and dry seasons will improve understanding on the effects of environmental variables, organic detritus input and decomposition on soil respiration trends in the tropics. A trenching experiment was conducted to quantify Rs and Rh over a period of 30 months, and climatic variables, soil bulk density, water and air filled pore space, fine root biomass, decomposition ratio and litterfall coinciding with soil respiration measurements were recorded using chamber methods. The Rs was significantly different across time where elevated levels (518.60-784.08 $\left.\mathrm{mg} \mathrm{CO}_{2} \mathrm{~m}^{-2} \mathrm{~h}^{-1}\right)$ were observed during wet season but Rh did not differ. The Rh contributed a larger portion (73-90\%) to Rs compared to autotrophic respiration ( $\mathrm{Ra}$ ). Soil temperatures and relative humidity were significantly different in Rs and Rh plots. Wet season also significantly elevated fine root biomass (222.93-237.96 $\mathrm{g} \mathrm{m}^{-2}$ ), fine root decomposition ratio $(0.49)$ and litterfall $\left(304.64 \mathrm{~g} \mathrm{~m}^{-2}\right)$ that contributed to Rs. It was concluded that climatic and primary productivity variables affect $\mathrm{Rs}$ and $\mathrm{Rh}$ in a tropical forest ecosystem. However, long term temporal and spatial observations are necessary to improve the understanding of forecast soil $\mathrm{CO}_{2}$ sequestration dynamics in a changing environment.
\end{abstract}

Keywords: Soil fluxes, tropical climate, secondary forest, root respiration, temporal variation, fine roots

\section{INTRODUCTION}

Soil respiration (Rs) is defined as the production of carbon dioxide by organisms and plant parts in soil. Organisms include soil microbes and microfauna, and the plant parts are roots and rhizomes in the soil (Luo \& Zhou 2006). Soil respiration represents an important source of carbon dioxide in the biosphere. It is known to be the second largest flux after gross primary productivity in the global carbon $(\mathrm{C})$ cycle, contributing 20-40\% of atmospheric annual C input (Raich \& Schlesinger 1992, Bond-Lamberty $\&$ Thomson 2010). It plays a vital role in regulating the dynamics of soil carbon and its possible feedbacks to global warming. An earlier study by Hashimoto et al. (2015) estimated that the mean annual $\mathrm{CO}_{2}$ fluxes from soils to atmosphere from 1965 to 2012 were $91 \mathrm{Pg} \mathrm{C}_{\text {year }}{ }^{-1}$ whereby the tropical region contributed $64 \%$ (Wanyama et al. 2019). The Rs is the sum of autotrophic respiration $(\mathrm{Ra})$ of roots and rhizosphere organisms, and heterotrophic respiration ( $R h)$ of bacteria and fungi decomposition of organic matter and soil faunal activity in the organic and mineral horizons (Hanson et al. 2000). Recent studies moved towards quantifying $\mathrm{C}$ losses from soil respiration, both at a local, regional and global scale, in order to quantify carbon balance and prediction of $\mathrm{C}$ flux trends for the future. Studies have shown that both autotrophic and heterotrophic soil respiration varies between land use types and seasons (Kosugi et al. 2007; Arevalo et al. 2010; Adachi et al. 2017). The Ra was reported to be sensitive to soil moisture and daytime net ecosystem exchange, while heterotrophic respiration was sensitive to soil temperature and soil moisture (Vargas et al. 2013; Hanpattanakit et al. 2015). Sayer \& Tanner (2010) discussed how $\mathrm{Ra}$ is influenced by aboveground assimilation and growth, and heterotrophic respiration is driven by substrate availability such 
as litterfall. Considering previous literature, the abiotic and biotic factors that influence Rs and $\mathrm{Rh}$ independently or interactively vary greatly and create a need to partition soil respiration measurements.

However studies related to partitioning of soil respiration is still insufficient in the tropics. Recent reports captured the inclusiveness of soil moisture in causing major seasonal variations of Rs in tropical forests (Adachi et al. 2006, Ohashi et al. 2008, Jeyanny et al. 2015). Nevertheless the biotic features that contribute to Rs is still poorly understood, and this includes the dynamics of root and microbial biomass in relation to soil respiration (Grayson et al. 2001, Barba et al. 2018). Thus, we believe that estimating $\mathrm{Ra}$ and $\mathrm{Rh}$ components will improve understanding on the implications of environmental change (abiotic), root and microbial (biotic) dynamics on soil $\mathrm{C}$ cycling and sequestration. The main objective was to analyse the temporal variations of $\mathrm{Rs}$ and $\mathrm{Rh}$, and the climatic and biotic factors that influence them. This will lead to developing improved models on soil carbon dynamics in tropical forest ecosystem and elucidate their responses to the changing climate.

\section{MATERIALS AND METHODS}

\section{Site description}

The research was carried out in a secondary lowland forest in Pahang, West Malaysia. This site was chosen as secondary data were available from previous studies (Jeyanny et al. 2014, Jeyanny et al. 2015). It is known as Jengka Virgin Jungle Reserve (Jengka VJR), and located at Jengka 18, Pahang ( $3^{\circ}$ 34.99' $\mathrm{N} 102^{\circ} 34.29^{\prime} \mathrm{E}$ ), at $50-90 \mathrm{~m}$ above sea level with slope ranging from $2-8^{\circ}$. The soil type here is silty clay loam from the Durian Series (Typic Paleudult). The major botanical families recorded were Phyllanthaceae, Euphorbiaceae and Dipterocarpaceae with trees ranging from 4 to $50 \mathrm{~m}$ in height (median $8 \mathrm{~m}$ ) and diameter at breast height $(\mathrm{DBH})$ ranging from $5-70 \mathrm{~cm}$ (median $8.35 \mathrm{~cm}$ ). Common genera were Shorea, Aporosa and Croton. The total number of trees were $1383 \mathrm{ha}^{-1}$. Jengka VJR was reported to have been logged once between 1968 to 1969, and known as a secondary forest with minimal disturbances (Putz \& Redford 2010, Laidlaw 2011). Since the climate in Malaysia is governed by two monsoon seasons, heavy rainfall is expected from November to March (wet season) whereas May to September has relatively drier weather. The mean monthly rainfall and temperature for Jengka VJR recorded from 2011 to 2012 showed values ranging from $200-350 \mathrm{~mm}$ and 25 to $30{ }^{\circ} \mathrm{C}$ (Jeyanny et al. 2015). The current data recorded were 20-455 mm and 26 to $28^{\circ} \mathrm{C}$ from October 2017 to June 2019 (Figure 1).

\section{Experimental plots}

A transect running from North East towards South West was established in the study plot, whereby 60 quadrants measuring $10 \times 10 \mathrm{~m}$ were established systematically (0.6 ha). Eight subplots were established for trenched and untrenched plots for Rs and Rh measurements within the main study area. All plots were located 3 meters away from trees and carefully selected with the absence of ant or termite mounds to avoid root presence and macrofaunal respiration.

The trenched plots were made using a chopper in April 2017, 6 months prior to data collection. The dimensions were $1 \mathrm{~m} \times 1 \mathrm{~m}$ with a depth of $0.8 \mathrm{~m}$. A 6 months period was allowed for dead root decomposition before measurements were collected to ascertain, and only $\mathrm{Rh}$ was recorded for trenched plots. It was ensured that trenches were void of any roof reinvasion, through maintenance of trench plots via inspection and clippings on a periodic basis, before $\mathrm{CO}_{2}$ measurements were recorded.

\section{Soil respiration (Rs) measurement}

An automated soil $\mathrm{CO}_{2}$ flux system (LI-8100) was used to measure soil $\mathrm{CO}_{2}$ fluxes to the atmosphere. The instrument was calibrated with standard $\mathrm{CO}_{2}$ gas, twice within the duration of measurement, and also using the zero and span procedures before measurements were recorded. Measurements were taken between 1000 and 1200 hours, where daily soil $\mathrm{CO}_{2}$ fluxes were assumed to be at the highest rate (Luo \& Zhou 2006). Periodic night time soil respiration was not accounted for, as random measurements done in October 2018 and February 2019 showed minimal diurnal variations. Thus, sampling replications (16) were constrained by time as access difficulty from one point to another within the forest reserve. Before measurements, soil collars with a 


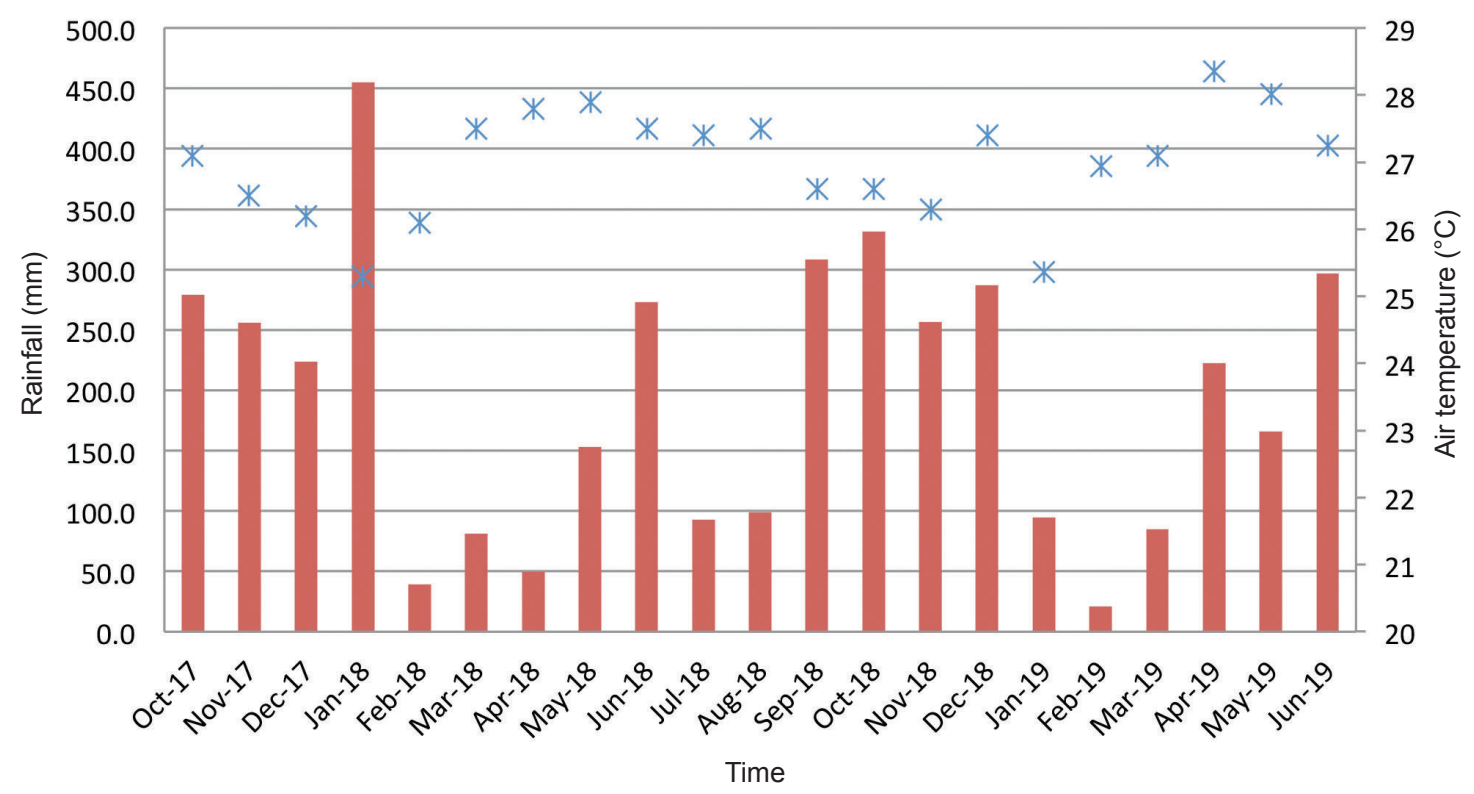

Figure 1 Mean monthly rainfall and temperature at study site from October 2017-June 2019

dimension of $10 \times 10 \mathrm{~cm}$ was placed on soil surface and inserted into the soil to a depth of $2 \mathrm{~cm}$, leaving a headspace of $3 \mathrm{~cm}$. Soil disturbance during collar insertion was minimised. During measurement, the lid of the chamber was closed and the air was circulated in a gap between the collar headspace and the chamber. Once the $\mathrm{CO}_{2}$ concentration in the chamber had stabilised (approximately 30 seconds), the concentration was recorded for about 60 seconds. Each measurement was repeated twice at each sampling point. The flux rate was determined by the system's software by calculating the initial slope of a fitted exponential curve at the ambient $\mathrm{CO}_{2}$ concentration, and given in units of $\mu \mathrm{g}$ mol $\mathrm{CO}_{2} \mathrm{~m}^{-1} \mathrm{~s}^{-1}$. These values were converted to $\mathrm{mg}$ $\mathrm{CO}_{2} \mathrm{~m}^{-2} \mathrm{~h}^{-1}$ by mathematical functions. The values for Ra was computed by Rs-Ra.

\section{Ancillary measurements}

At each time of soil respiration measurements at trenched and untrenched plots, eight replicates of bulk density samples at $5 \mathrm{~cm}$ depth were retrieved using core rings of $100 \mathrm{~cm}^{3}$, close to the soil flux measurement sampling point, to determine soil porosity and volumetric soil water content. Water filled pore space (WFPS) was calculated from the soil water content and bulk density. The particle density used was average for mineral soils, $2.65 \mathrm{~g} \mathrm{~cm}^{-3}$ (Osman et al. 2012). Soil bulk density and soil water content were determined by recording the initial weight and later oven dried at $105{ }^{\circ} \mathrm{C}$ for 24 hours until constant weight. The WFPS, which was the ratio of volumetric water content to the total porosity of soil, was calculated, whereas air filled pore space (AFPS) was equivalent to 1-WFPS. Soil temperature was determined using an additional temperature probe which was inserted into soil at $5 \mathrm{~cm}$ depth, and measurement was taken when the values stabilised. Relative humidity values were obtained from the LI-8100 $\mathrm{CO}_{2}$ flux system.

\section{Litterfall, fine root biomass and fine root decomposition}

Aboveground litterfall including materials such as leaves, branches and productive organs were collected in littertraps measuring $1 \mathrm{~m} \times 1 \mathrm{~m}$, placed with netting material $1 \mathrm{~m}$ above the ground. The materials were collected every 4 months and oven dried at $80{ }^{\circ} \mathrm{C}$ to record litterfall biomass. Sequence soil cores were collected up to $20 \mathrm{~cm}$ during every trip on the same dates with soil flux measurements. On each date, 30 soil cores were collected using stainless steel tube of $32 \mathrm{~mm}$ inner diameter. Collected soil was then washed and sieved using $0.05 \mathrm{~mm}$ mesh opening to collect fine roots which were then air-dried and separated to living and dead roots (Hishi \& Takeda 2005). Fine roots make up more than $50 \%$ of the total $\mathrm{C}$ found in the upper $10 \mathrm{~cm}$ of soil and their decomposition contributes 
to soil respiration (Trumbore et al. 2006). In this study, fine roots were defined as less than $2 \mathrm{~mm}$ in diameter.

Roots were oven-dried at $80^{\circ} \mathrm{C}$ until constant weight and the values for fine root biomass (living roots) were reported. Approximately 1.5 gram of fine roots were placed into $10 \mathrm{~cm} \times 10 \mathrm{~cm}$ root bags with a $211 \mu \mathrm{m}$ mesh opening using netting material. A total of 120 root bags were buried to $10-15 \mathrm{~cm}$ soil depth and collected at corresponding time intervals. For each responding time intervals, 20 root bags were collected. Collected root bags were washed, air dried and oven-dried $\left(80^{\circ} \mathrm{C}\right)$ for remaining mass. Decomposition ratio is estimated as [(initial mass - remained mass)/initial mass].

\section{Statistical analysis}

Analysis of variance (ANOVA) for soil $\mathrm{CO}_{2}$ fluxes, relative humidity, soil temperature, WFPS, AFPS, fine root biomass, root decomposition ratio and litterfall biomass between sampling periods were carried out using Statistical Analysis System version 9.2, and the sampling interval means were compared according to Student-NewmanKeuls Test.

\section{RESULTS}

\section{Meteorological data}

The meteorological data showed that there was heavy rainfall (279.0-455 $\mathrm{mm}$ ) during the months of October 2017 to January 2018 that reduced air temperatures (Figure 1). However, a distinctive dry period $(39.3-150.3 \mathrm{~mm})$ was observed in February and May 2018 which elevated air temperatures $\left(26.1-27.5^{\circ} \mathrm{C}\right)$. There was a sudden surge in rainfall in June 2018 ( $273 \mathrm{~mm}$ ), but the period up to August 2018 were drier before the onset of wetseason from September to December 2018 (308.8 $\mathrm{mm}-287.0 \mathrm{~mm}$ ) with normalised air temperatures of $27.4{ }^{\circ} \mathrm{C}$. Besides transition during monsoon, this variability in climate is attributed to El Niño Southern Oscillation (ENSO) phenomenon (Wong et al. 2016).

\section{Soil respiration}

Soil bulk density, WFPS, AFPS, soil carbon dioxide respiration, relative humidity and soil temperature were measured, as shown in Table 1 and Figures 2-4. There were no significant differences for soil bulk density, WFPS and AFPS (Table 1). Soil bulk density for the Rs and Rh plots ranged from 1.11 to $1.24 \mathrm{~g} \mathrm{~cm}^{-3}$ and 1.10 to $1.25 \mathrm{~g} \mathrm{~cm}^{-3}$, respectively. Water filled pore space and air filled pore space were similar for both plots, from 52.80 to $57.97 \%$ and 41.82 to $47.50 \%$, respectively.

The Rs were significantly different in elevated levels (518.60-784.08 $\mathrm{mg} \mathrm{CO}_{2} \mathrm{~m}^{-2} \mathrm{~h}^{-1}$ ), recorded for the period of October 2017, February 2018 and February 2019, compared to the rest of the months (Figure 2). Values for $\mathrm{Rh}$ were not significantly different and ranged between 201.68-632.02 mg $\mathrm{CO}_{2} \mathrm{~m}^{-2} \mathrm{~h}^{-1}$. The Ra constituted of 70.6-152.06 $\mathrm{mg} \mathrm{CO}_{2} \mathrm{~m}^{-2} \mathrm{~h}^{-1}$. The $\mathrm{Rh} / \mathrm{Rs}$ ratios from October 2017 to June 2019 were $0.78,0.85,0.74,0.73,0.81$ and 0.90 , respectively. Soil temperatures were relatively lower in Rs plots, and values for $\mathrm{Rs}$ and $\mathrm{Rh}$ were significantly lower during October 2017 and February 2018 compared to June 2018 to

Table 1 Mean values for soil bulk density, water filled pore space and air filled pore space in Jengka Forest Reserve, Pahang

\begin{tabular}{ccccccc}
\hline $\begin{array}{c}\text { Time } \\
\text { Days }\end{array}$ & Plots & $\begin{array}{c}\text { October } 2017 \\
0\end{array}$ & $\begin{array}{c}\text { February 2018 } \\
\text { Jun 2018 }\end{array}$ & $\begin{array}{c}\text { October 2018 } \\
240\end{array}$ & 360 & February 2019 \\
\hline $\begin{array}{c}\text { Bulk density } \\
\left(\mathrm{g} \mathrm{cm}^{3}\right)\end{array}$ & Rs & $1.22(0.05)$ & $1.25(0.05)$ & $1.16(0.05)$ & $1.23(0.05)$ & $1.11(0.03)$ \\
WFPS (\%) & Rs & $1.15(0.07)$ & $1.25(0.05)$ & $1.12(0.02)$ & $1.16(0.07)$ & $1.10(0.04)$ \\
& Rh & $53.86(2.01)$ & $52.80(2.28)$ & $56.27(1.51)$ & $53.75(1.99)$ & $57.97(1.41)$ \\
AFPS (\%) & Rs & $46.14(2.01)$ & $47.19(2.25)$ & $43.73(1.54)$ & $46.25(2.00)$ & $42.03(1.40)$ \\
& Rh & $43.71(2.62)$ & $47.50(1.90)$ & $42.25(1.04)$ & $43.81(2.65)$ & $41.82(1.60)$ \\
\hline
\end{tabular}

Values in parentheses denotes standard error; $\mathrm{Rs}=$ total soil respiration plots, $\mathrm{Rh}=$ heterotrophic respiration plots, $\mathrm{n}=8$ 


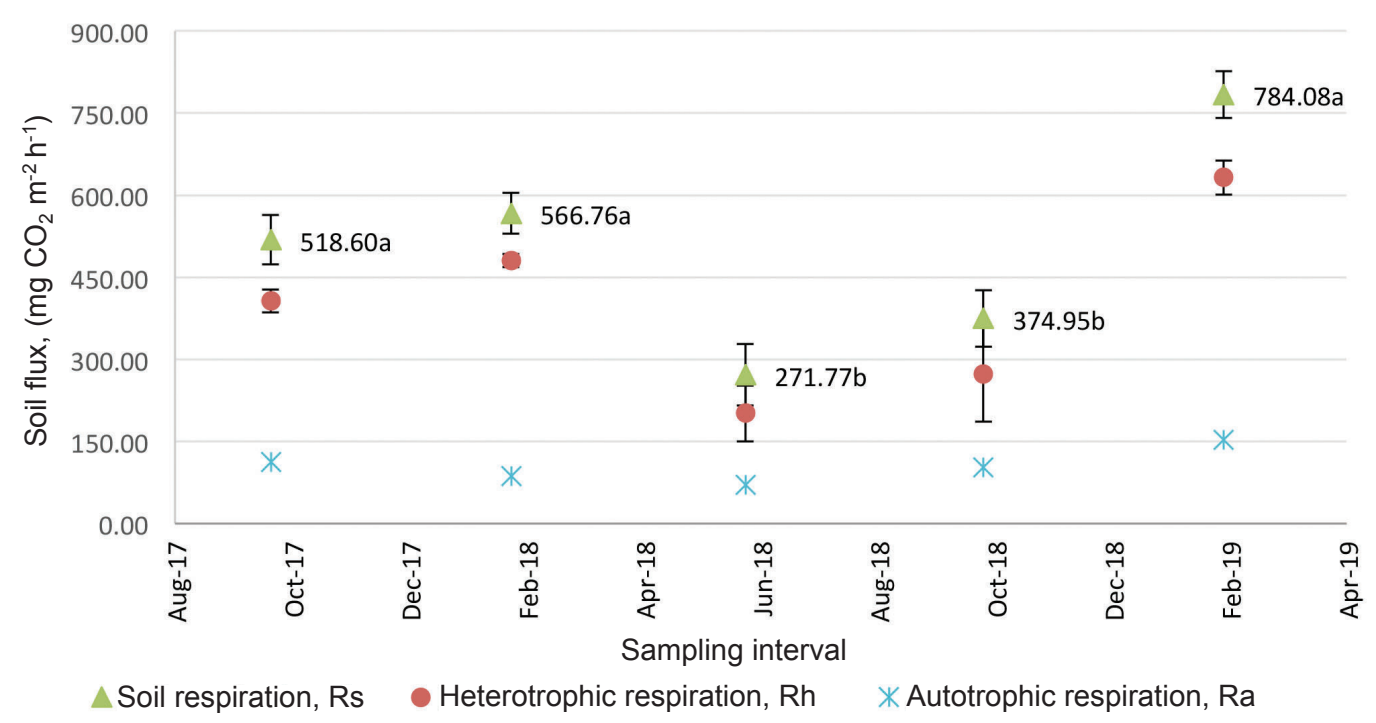

Figure 2 Mean average total soil respiration (Rs), heterotrophic respiration (Rh) and autotrophic respiration ( $\mathrm{Ra}$ ) at study site from October 2017-June 2019, $\mathrm{n}=8$; mean values followed by different letters within each column are significantly different for sampling interval by Student Newmann Keul Test $(\mathrm{p} \leq 0.05)$; error bars represent standard errors

February 2019, which increased 12-13\% (Figure 3). Generally, relative humidity recorded in Rs plots were similar most of the time and variations between Rs and Rh were minimal. The relative humidity in Rs and Rh plots were significantly higher in February 2018 and June 18 (4\%), compared to October 2017 (Figure 4). Values significantly surged higher $(5-6 \%)$ in October 2018 compared to the previous readings and plummeted (3-4\%) in October 2019.

\section{Litterfall, fine root biomass and fine root decomposition}

Fine root biomass, fine root decomposition ratio and litterfall differed significantly across time (Table 2). It was noted that the highest fine root biomass was collected in October 2017 and October 2018 during the wet season and was significantly (1.3-1.6 folds) higher than in the drier periods of February 2018 and February 2019. Lowest values were recorded in June 2018, at least 33\% lower than February 2018. Lower trends in root decomposition ratio (0.23-0.28) were observed in February 2018 and June 2018. Root decomposition ratios in October 2018 significantly increased 2 folds compared to the previous months of heavy precipitation. In February 2019, root decomposition ratio was the highest $(0.7743), 58 \%$ higher than October 2018. Litterfall in both February and June 2018 recorded lower values (232.99-250.67 $\mathrm{g} \mathrm{m}^{-2}$ ) compared to October 2018 which surged 21-31\% in biomass. The lowest value was recorded in February 2019 (135.40 $\left.\mathrm{g} \mathrm{m}^{-2}\right)$.

\section{DISCUSSION}

\section{Response of soil respiration to environmental variables}

The observations on environmental variables support a previous study (Jeyanny et al. 2015). High precipitation was cited in October and November 2011 (250-350 mm), and a drier period was observed from June to September (2011 and 2012), in line with the monsoonal season. Total soil respiration were elevated during heavy rainfall in October 2017 and remained high in February 2018, attributed to several factors related to abiotic and biotic elements. Both Kosugi et al. (2007) and Jeyanny et al. (2015) showed that Rs increased in wet season and reduced during drier periods. The $\mathrm{Rh} / \mathrm{Rs}$ ratio did not show seasonal patterns but further reinstated the larger portion of heterotrophic respiration controlling soil respiration in the tropics (Hanson et al. 2000, Hanpattanankit et al. 2015) .

Soil temperature and moisture plays important roles in root and microbial respirations. With the availability of wetter soils and preferable 


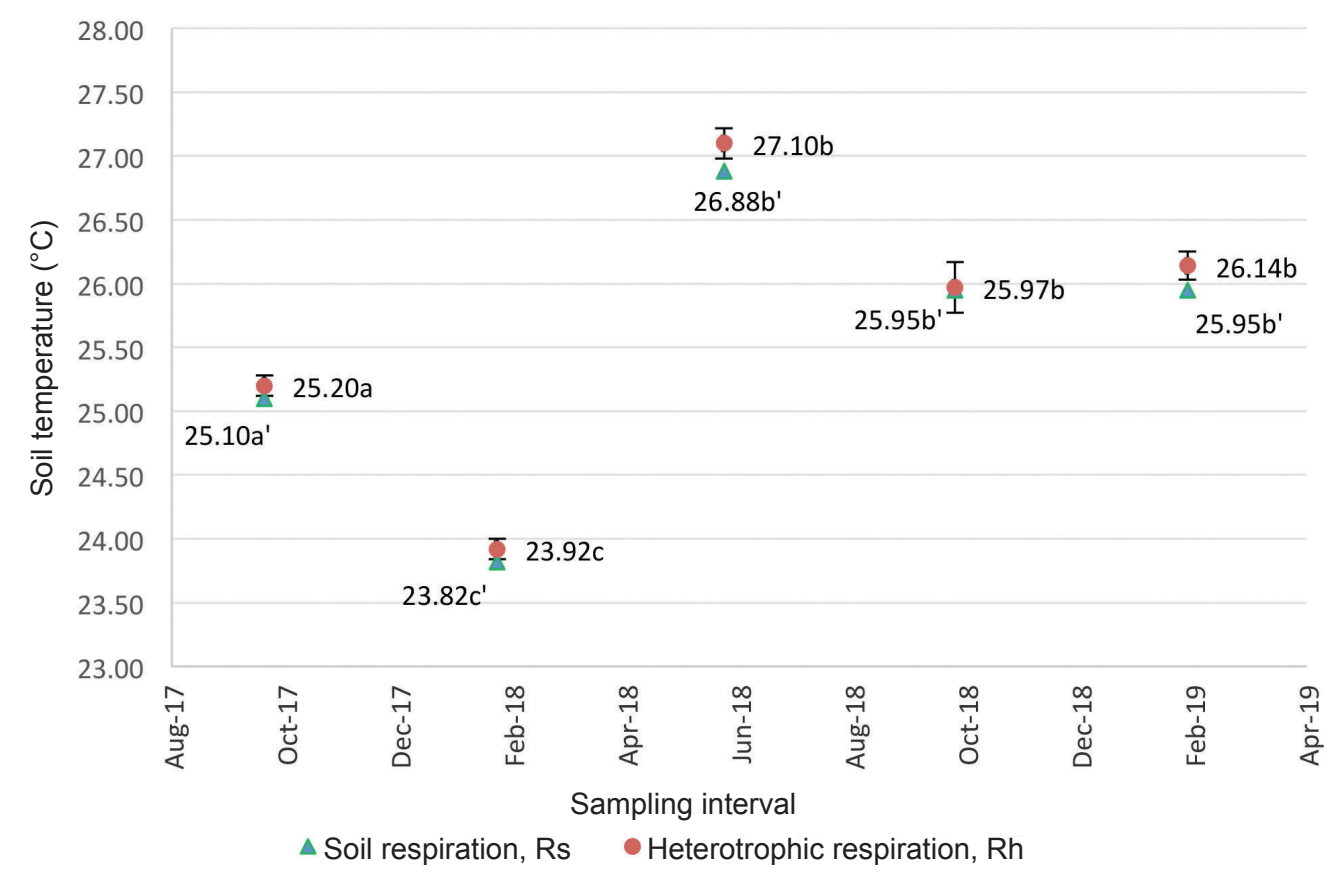

Figure 3 Mean average soil temperature for soil respiration (Rs) and heterotrophic respiration (Rh) plots at study site from October 2017-June 2019, $\mathrm{n}=8$; mean values followed by different letters within each column are significantly different for sampling interval by Student Newmann Keul Test $(\mathrm{p} \leq 0.05)$, true for letters with prime; error bars represent standard errors

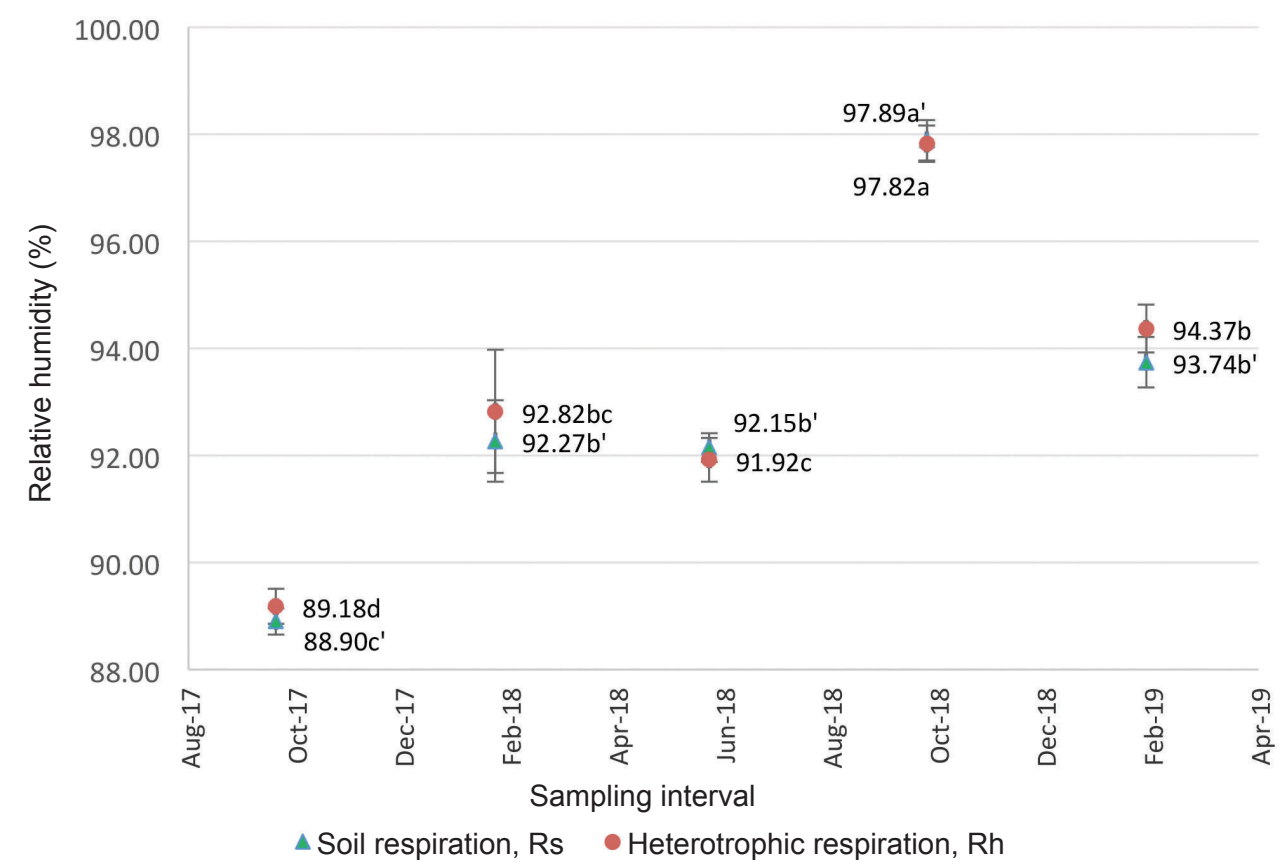

Figure 4 Mean average relative humidity for soil respiration (Rs) and heterotrophic respiration (Rh) plots at study site from October 2017-June 2019, $\mathrm{n}=8$; mean values followed by different letters within each column are significantly different for sampling interval by Student Newmann Keul Test $(\mathrm{p} \leq 0.05)$; true for letters with prime; error bars represent standard errors 
Table 2 Fineroot biomass, fine root decomposition ratio and litterfall at study site from October 2017-June 2019

\begin{tabular}{cccccc}
\hline Time & October 2017 & February 2018 & Jun 2018 & October 2018 & February 2019 \\
Days & 0 & 120 & 240 & 360 & 480 \\
\hline Fineroot biomass $\left(\mathrm{g} \mathrm{m}^{-2}\right)$ & $237.96 \mathrm{a}$ & $148.01 \mathrm{ab}$ & $98.70 \mathrm{~b}$ & $222.93 \mathrm{a}$ & $170.53 \mathrm{ab}$ \\
$\mathrm{n}=30$ & $(0.03)$ & $(0.03)$ & $(0.04)$ & $(0.10)$ & $(0.05)$ \\
Fine root decomposition ratio & $\mathrm{nd}$ & $0.24 \mathrm{c}$ & $0.28 \mathrm{c}$ & $0.49 \mathrm{~b}$ & $0.77 \mathrm{a}$ \\
$\mathrm{n}=20$ & & $(0.01)$ & $(0.01)$ & $(0.03)$ & $(0.02)$ \\
Litterfall $\left(\mathrm{g} \mathrm{m}^{-2}\right)$ & $243.65 \mathrm{~b}$ & $232.99 \mathrm{~b}$ & $250.67 \mathrm{~b}$ & $304.64 \mathrm{a}$ & $135.40 \mathrm{c}$ \\
$\mathrm{n}=20$ & $(13.25)$ & $(15.23)$ & $(24.5)$ & $(12.28)$ & $(13.06)$ \\
\hline
\end{tabular}

Mean values followed by different letters within each rows are significantly different for sampling interval by Student Newmann Keul Test $(\mathrm{p} \leq 0.05)$; values in parentheses represents standard errors; $n d=$ not determined due to the initial start of root bag experiment to estimate decomposition

temperatures $\left(23.8-25.2{ }^{\circ} \mathrm{C}\right)$ acceleration of microbial and root respirations are possible, in line with incremental metabolic rates of microbes coinciding with root respiration (Hui et al. 2001, Luo \& Zhou 2006). Wang et al. (2017) reported that soil temperature significantly correlated with soil $\mathrm{CO}_{2}$ fluxes and this was true in the present study, where an antagonistic relationship existed throughout the study period, except for February 2019. It was also important to note that soil temperature values were lower in Rs plots compared to Rh plots, agreeing with Kopittke et al. (2013). This could be due to the availability of increased soil moisture content in Rs plots that regulated soil temperatures.

Relative humidity is the ratio of partial pressure of water vapour to equilibrium vapour pressure of water at a given temperature. Although significant values were found in changes related to relative humidity, this could be due to the seasonal patterns at the study site which did not deviate from normal values for tropical forests (Melling et al. 2005). When relative humidity is low, plants experience water stress and stomatal closure, and reduced photosynthates leading to low levels of Rs. However, this was not true for October 2017, February 2018 and October 2018, where an antagonistic relationship was apparent for Rs versus relative humidity, due to the dominance of other inherent factors which were not investigated.

Total $\mathrm{CO}_{2}$ fluxes in Rs plummeted during June 2018 at drier season and remained low during wet season in October 2018. Drier season escalates soil temperatures (Hanpattanankit et al. 2015), which may have significantly reduced the Rs in June 2018. However, in October 2018, the wet conditions did not directly affect the low Rs. This could be due to elevated soil temperatures and relative humidity at the microsite.

Soil respiration increased in February 2019. Visual observations confirmed that this anomaly was exacerbated by disturbances induced by pathway construction of private proprietors, $350 \mathrm{~m}$ away from the research plot. As the area experienced transition of land use, the Rs, soil temperature and relative humidity remained elevated. The clearing also resulted windthrows in the plot (due to open canopy effects) that could have elevated the Rs values, due to greater feed for microbial respiration. During this time, soil WFPS recorded the highest values $(57 \%)$ comparative to other times (Table 1). Although the sites were intact, disturbances at adjacent areas may have contributed to this phenomenon.

\section{Contribution of heterotrophic respiration $(\mathrm{Rh})$ and autotrophic respiration (Ra)}

Throughout the study, Rh were markedly higher, constituting of at least $73-84 \%$ of Rs compared to Ra. It did not show any significant trends and its values differing from Ra may be due to temperature sensitivity towards microbial activity (Jiao \& Wang 2019). Comparable to Rs, $\mathrm{Rh}$ had the tendency to have lower fluxes due to the omission of Ra (Hanpattanakit et al. 2015, Hergoualc'h et al. 2017). It is also likely that rainfall patterns and soil water content affect $\mathrm{Rh}$ (Sayer and Tanner 2010). The increased soil water content in February 2019, compared to other months, could have been due to direct movement of water percolation induced by the absence of root interception, resulting from the 
clearing activities outside the plot. In contrary, the observations did not tally with Adachi et al. (2006) whom reported that Rs was negatively correlated with soil water content in a secondary forest, Pasoh, Negeri Sembilan.

The Ra somewhat ranged from 15-27\% in tropical forests, unlike reports in other boreal and temperate forests which escalated during growing seasons and remained dormant during non-growing season (Li et al. 2013, Jiao \& Wang 2019, Hanson et al. 2000). However, this theory did not fit the current study site. The insensitivity of Ra towards environmental variables may be due to physiological and phenological traits of the diversity of root species in the environment (Luo \& Zhou 2010).

\section{Litterfall, fine root biomass and fine root decomposition}

Fine root biomass, fine root decomposition ratio and litterfall increased during the wet seasons of October 2017 and 2018. During the drier periods (February-June 2018 and February 2019), there was a decrease in fine root biomass and litterfall. Organic matter decomposition accelerated with the availability of moisture and temperature. Litterfall provides substantial amounts of carbon substrate to microbial respiration (Maier \& Kress 2000, Berg \& McClaugherty 2008), contributing to the fluxes recorded earlier during the wet season. Precipitation stimulates root absorption of mineral nutrients and enhances substrate availability for microbial decomposition and litterfall production (Davidson \& Janssens 2006). Changes in these processes would activate root growth leading to increased root biomass, as seen in this study. Increased root biomass is parallel with increased growth and primary productivity which occurs during wet seasons, similar to reports by Violita et al. (2016) and Jimenez et al. (2009) in tropical ecosystems of Indonesia and Amazon. In contrast, drier climate from February to June 2018 hinders root growth, resulting in lower fine root biomass and root decomposition ratios, as soil water availability becomes scarce, leading to minimal Rs as both roots and microorganisms thrive to maintain basic metabolism levels (Borken et al. 2008).

The increased Rs found in February 2019 is closely influenced by higher inputs of organic debris due to windthrows, which accelerates decomposition processes of fresh labile organic carbon (Luo \& Zhou 2006, Li et al. 2013). This was confirmed with the higher fine root decomposition ratios found in February 2019 (Table 2). It was hypothesised that favourable conditions of higher soil temperatures and relative humidity (Figures 3-4), combined with better soil water percolation (Table 1) due to the effects of clearing, resulted this observations. Wang et al. (2017) also reported a similar situation of increased Rs, which was most likely due to excess organic debris produced from harvesting activities. Although the research plot was intact and still within forest boundaries, any drastic activities within its vicinity was liable to cause divergence in data due to edge effects. Thus, the results for soil fluxes, fine root biomass and litterfall were similar to previous studies in tropical forest ecosystems with the given climatic similarities (Table 3). It was noted that soil respiration varied with spatial and temporal changes, displaying a range of 163.0-2,634.10 $\mathrm{mg} \mathrm{CO} \mathrm{CO}_{2} \mathrm{~m}^{-2} \mathrm{~h}^{-1}$. Although most studies did not counter fine root biomass and litterfall, values in this study concurred with Hergoulc'h et al. (2017) and Jiang et al. (2017) for litterfall. The fine root biomass was similar to a study done in Pasoh, Negeri Sembilan secondary forest (Adachi et al. 2006). Nevertheless, the values for fine root biomass were relatively higher (35-44\%) compared to studies carried out in Central Kalimantan, Indonesia and Hainan island, China due to site specific variations (Hergoulc'h et al. 2017, Jiang et al. 2017).

\section{CONGLUSION}

The trenching experiment revealed that soil Rs can be partitioned into $\mathrm{Rh}$ and $\mathrm{Ra}$. The $\mathrm{Rh}$ constituted close to $73-90 \%$ of Rs. The Ra values were stable and constituted of $15-27 \%$. Generally, Rs was mainly controlled by climatic variations such as precipitation, soil temperature and relative humidity that occurred during wet/ dry season. Other drivers that influenced Rs significantly were fine root biomass, litterfall and fine root decomposition ratios. Future research in tropical forests should account for variables related to primary production, to understand long term soil respiration trends. Based on the current findings, both Rs and $\mathrm{Rh}$ responded differently to site specific conditions and should be considered separately during wet and dry 


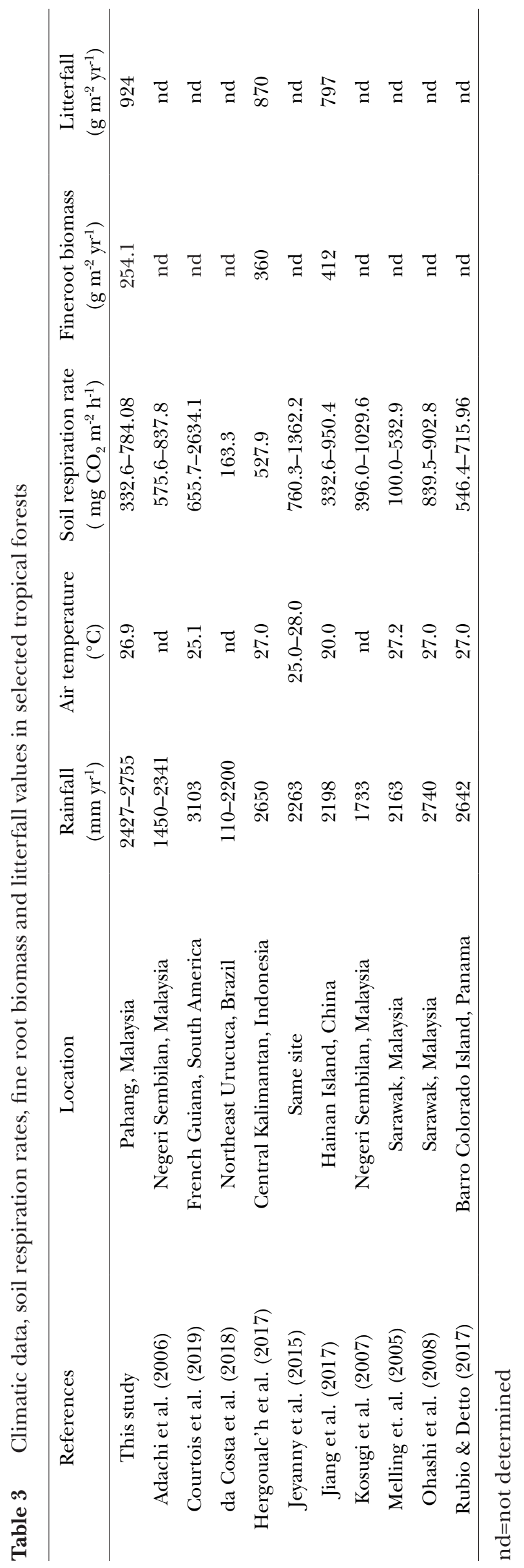


seasons, in order to capture variations useful for soil carbon sequestration and efflux models for accurate predictions.

\section{ACKNOWLEDGEMENTS}

This study was financially supported by the International Foundation of Science-South East Asian Regional Center for Graduate Study and Research in Agriculture (IFS-SEARCA) Collaborative Research Fund (J-1-D-6024-1). The authors would like to thank the staff of Forest Research Institute Malaysia and Universiti Putra Malaysia for field and technical assistance.

\section{REFERENCES}

ADAChi M, BekKU YS, Rashidah W, OKUda T \& KoIZUmi H. 2006. Differences in soil respiration between different tropical ecosystems. Applied Soil Ecology 34: 258-265.

Adachi M, Ito A, Yonemura S \& Takeuchi W. 2017. Estimation of global soil respiration by accounting for land-use changes derived from remote sensing data. Journal of Environmental Management 200: 97-104. https://doi. org/10.1016/j.jenvman.2017.05.076.

Arevalo CB, Bhatti JS, Chang SX, Jassal RS \& Sidders D. 2010. Soil respiration in four different land use systems in north central Alberta, Canada. Journal of Geophysical Research: Biogeosciences 115: 1-12. https:/ / doi.org/10.1029/2009jg001006.

Barba J, Cueva A, Bahn M et Al. 2018. Comparing ecosystem and soil respiration: review and key challenges of tower-based and soil measurements. Agricultural and Forest Meteorology 249: 434-443.

Berg B \& Mcclaugherty C. 2008. Plant Litter: Decomposition, Humus Formation, Carbon Sequestration. Springer Verlag, Berlin.

Bond-Lamberty B \& Thomson A. 2010. Temperatureassociated increases in the global soil respiration record. Nature 464: 579-582.

Borken W, Savage K, Davidson EA \& Trumbore SE. 2006. Effects of experimental drought on soil respiration and radiocarbon efflux from a temperate forest soil. Global Change Biology 12: 177-93.

Courtois EA, Stahl C \& Burban B. 2019. Automatic highfrequency measurements of full soil greenhouse gas fluxes in a tropical forest. Biogeosciences 16: 785-796.

Da Costa END, De Souza MFL, Marrocos PCL, Lobão D \& DA SiLva DML. 2018. Soil organic matter and $\mathrm{CO}_{2}$ fluxes in small tropical watersheds under forest and cacao agroforestry. PloS one 13: e0200550.

DAVIDSOn EA \& JANSSENS IA.2006 Temperature sensitivity of soil carbon decomposition and feedbacks to climate change. Nature 440: 165-73.

Grayston SJ, Griffith GS, Mawdsley Jl, Campbell CD, BARDGETT RD. 2001. Accounting for variability in soil microbial communities of temperate upland grassland ecosystems. Soil Biology E Biochemistry 33: 533-551.
Hanpattanakit P, Leclerc MY, Mcmillan AM et al. 2015. Multiple timescale variations and controls of soil respiration in a tropical dry dipterocarp forest, western Thailand. Plant and Soil 390: 167-181.

Hanson PJ, Edwards NT, Garten CT \& Andrews JA. 2000. Separating root and soil microbial contributions to soil respiration: a review of methods and observations. Biogeochemistry 48: 115-146. https:// doi.org/10.1023/A:1006244819642.

Hashimoto S, Carvalhais N, Ito A, Migliavacca M, Nishina K \& Reichstein M. 2015. Global spatiotemporal distribution of soil respiration modelled using a global database. Biogeosciences 12: 4121-4132. https://doi.org/10.5194/bg-12-4121-201.

Hergoualc' h K, Hendry DT, Murdiyarso D \& Verchot LV. 2017. Total and heterotrophic soil respiration in a swamp forest and oil palm plantations on peat in Central Kalimantan, Indonesia. Biogeochemistry 135: 203-220.

Hishi T \& TAKedA H. 2005. Life cycles of individual roots in fine root system of Chamaecyparis obtusa Sieb. et Zucc. Journal of Forest Research 10: 181-187.

Hui D, Luo Y, Cheng W, Coleman JS, Johnson DW \& Sims DA. 2001. Canopy radiation-and water-use efficiencies as affected by elevated $\left[\mathrm{CO}_{2}\right]$. Global Change Biology 7: $75-91$.

Jeyanny V, Husni M, Rasidah KW, Siva Kumar B, Arifin A \& M. Kamarul Hisham. 2014. Carbon stocks in different carbon pools of a tropical lowland forest and a montane forest with a varying topography. Journal of Tropical Forest Science 26: 560-571.

Jeyanny V, Husni M, Rasidah KW, Siva Kumar B, Muhammad Firdaus S \& ARIFIn A. 2015. Leaf litter decomposition and soil carbon dioxide fluxes across a climatic gradient in tropical montane and lowland forests. Journal of Tropical Forest Science 27: 472-487.

Jiang L, Ma S, Zhou Z ET AL. 2017. Soil respiration and its partitioning in different components in tropical primary and secondary mountain rain forests in Hainan Island, China. Journal of Plant Ecology 10: 791-799.

Jiao Z \& WANG X. 2019. Contrasting rhizospheric and heterotrophic components of soil respiration during growing and non-growing seasons in a temperate deciduous forest. Forests 10: 8 .

Jimenez EM, Moreno FH, Penuela MC, Patino S \& Lloyd J. 2009. Fine root dynamics for forests on contrasting soils in the Colombian Amazon. Biogeosciences 6: 2809-27.

Kopittke GR, Van Loon EE, Tietema A \& Asscheman, D. 2013. Soil respiration on an aging managed heathland: identifying an appropriate empirical model for predictive purposes. Biogeosciences 10: 3007-3038.

Kosugi Y, Mitani T, Itoh M et al. 2007. Spatial and temporal variation in soil respiration in a Southeast Asian tropical rainforest. Agricultural and Forest Meteorology 147: 35-47.

LAIDLAW RK 2011. Effects of habitat disturbance and protected areas on mammals of Peninsular Malaysia. Conservation Biology 14: 1639-1648.

Li P, YANG Y \& FAng J. 2013. Variations of root and heterotrophic respiration along environmental 
gradients in China's forests. Journal of Plant Ecology 6 : 358-367.

LUO Y \& ZHOU XH. 2010.Deconvolution analysis to quantify autotropic and heterotrophic respiration and their temperature sensitivities. New Phytol 188: 10-1.

Luo Y \& Zhou X. 2006. Soil Respiration and The Environment. Elsevier Academic Press, Burlington.

Maier CA \& Kress LW. 2000. Soil $\mathrm{CO}_{2}$ evolution and root respiration in 11 year-old loblolly pine (Pinus taeda) plantations as affected by moisture and nutrient availability. Canadian Journal of Forest Research 30 347-359.

Melling L, Hatano R \& Goh KJ. 2005. Soil $\mathrm{CO}_{2}$ flux from three ecosystems in tropical peat land of Sarawak, Malaysia. Tellus B 57: 1-11.

Ohashi M, Kumagai TO, Kume T, Gyokusen K, Saitoh TM \& Suzuki M. 2008. Characteristics of soil $\mathrm{CO}_{2}$ efflux variability in an aseasonal tropical rainforest in Borneo Island. Biogeochemistry 90: 275. doi:10.1007/s10533008-9253-0.

Osman KT. 2012. Soils: Principles, Properties and Management. Springer Science \& Business Media, Berlin.

Putz FE \& REDFoRd KH. 2010. The importance of defining 'forest': tropical forest degradation, deforestation, long-term phase shifts, and further transitions. Biotropica 42: 10-20.

Raich JW \& Schlesinger WH.1992. The global carbon dioxide flux in soil respiration and its relationship to vegetation and climate. Tellus B 44: 81-99.

Rubio VE \& Detтo M. 2017. Spatiotemporal variability of soil respiration in a seasonal tropical forest. Ecology and Evolution 7: 7104-7116.
Sayer EJ \& Tanner EV. 2010. A new approach to trenching experiments for measuring root-rhizosphere respiration in a lowland tropical forest. Soil Biology and Biochemistry 42: 347-352.

Trumbore S, Da Costa ES, Nepstad DC et al. 2006. Dynamics of fine root carbon in Amazonian tropical ecosystems and the contribution of roots to soil respiration. Global Change Biology 12: 217-229.

Vargas R, Detto M, Baldocchi DD \& Allen MF. 2013. Multiscale analysis of temporal variability of soil $\mathrm{CO}_{2}$ production as influenced by weather and vegetation. Global Change Biology 16: 1589-1605. doi:10.1111/ j.1365-2486.2005.00978.x.

Violita V, Triadiati T, Anas I \& Miftahudin M. 2016. Fine root production and decomposition in lowland rainforest and oil palm plantations in Sumatra, Indonesia. HAYATI Journal of Biosciences 23: 7-12.

Wang C, Ma Y, Trogisch S, Huang Y, Geng Y, SchererLORENZEN M \& HE JS. 2017. Soil respiration is driven by fine root biomass along a forest chronosequence in subtropical China. Journal of Plant Ecology 10: 36-46.

Wanyama I, Pelster De, Butterbach-Bahl K, Verchot LV, Martius C \& Rufino MC. 2019. Soil carbon dioxide and methane fluxes from forests and other land use types in an African tropical montane region. Biogeochemistry 143: 171-190.

Wong CL, Liew J, Yusop Z, Ismail T, Venneker \& Uhlenbrook S. 2016. Rainfall characteristics and regionalization in Peninsular Malaysia based on a high resolution gridded data set. Water 8: 500 . 